\title{
Robust Response to Plum pox virus Infection via Plant Biotechnology
}

\author{
Michel Ravelonandro ${ }^{1, *}$, Pascal Briard ${ }^{1}$, Ralph Scorza ${ }^{2}$, Ann Callahan ${ }^{2}$, Ioan Zagrai ${ }^{3}$, Jiban K. Kundu ${ }^{4}$ and \\ Chris Dardick ${ }^{2}$ \\ 1 UMR-BFP-1332, INRAE-Bordeaux, Bordeaux-UniversityII, 71 Avenue Bourleaux, \\ 33883 Villenave d'Ornon, France; pascal.briard@inrae.fr \\ 2 USDA-ARS Fruit Station, 2217 Wiltshire Road, Kearneysville, WV 25430, USA; ralph.scorza@gmail.com (R.S.); \\ ann.callahan@usda.gov (A.C.); Chris.Dardick@usda.gov (C.D.) \\ 3 Fruit Research and Development Station Bistrita, Drumul Dumitrei Nou street, 420127 Bistrita, Romania; \\ izagrai@yahoo.com \\ 4 Crop Research Institute, Drnovska 507/73, 16106 Praha, Czech Republic; jiban@vurv.cz \\ * Correspondence: michel.ravelonandro@wanadoo.fr
}

check for updates

Citation: Ravelonandro, M.; Briard, P.; Scorza, R.; Callahan, A.; Zagrai, I.; Kundu, J.K.; Dardick, C. Robust Response to Plum pox virus Infection via Plant Biotechnology. Genes 2021, 12, 816. https://doi.org/10.3390/ genes12060816

Academic Editor: Bin Yu

Received: 29 March 2021

Accepted: 25 May 2021

Published: 27 May 2021

Publisher's Note: MDPI stays neutral with regard to jurisdictional claims in published maps and institutional affiliations.

Copyright: (c) 2021 by the authors. Licensee MDPI, Basel, Switzerland. This article is an open access article distributed under the terms and conditions of the Creative Commons Attribution (CC BY) license (https:// creativecommons.org/licenses/by/ $4.0 /)$.

\begin{abstract}
Our goal was to target silencing of the Plum pox virus coat protein (PPV CP) gene independently expressed in plants. Clone C-2 is a transgenic plum expressing CP. We introduced and verified, in planta, the effects of the inverse repeat of CP sequence split by a hairpin (IRSH) that was characterized in the HoneySweet plum. The IRSH construct was driven by two CaMV35S promoter sequences flanking the CP sequence and had been introduced into C1738 plum. To determine if this structure was enough to induce silencing, cross-hybridization was made with the C1738 clone and the CP expressing but $P P V$-susceptible C2 clone. In total, 4 out of 63 clones were silenced. While introduction of the IRSH is reduced due to the heterozygous character in C1738 plum, the silencing induced by the IRSH PPV CP is robust. Extensive studies, in greenhouse containment, demonstrated that the genetic resource of $\mathrm{C} 1738$ clone can silence the $\mathrm{CP}$ production. In addition, these were verified through the virus transgene pyramiding in the BO70146 BlueByrd cv. plum that successfully produced resistant BlueByrd BO70146 × C1738 (HybC1738) hybrid plums.
\end{abstract}

Keywords: RNAi; hairpin; gene construct; Plum pox virus; Prunus domestica; resistance

\section{Introduction}

Genetic engineering in plants is an accurate technology aiming at the introduction of a foreign sequences into the genome. In order to overcome the incoming viral genome, the present technology consists of protecting plants against virus [1] through a pre-existing gene silencing approach. The challenging example is the $P P V$ that devastatingly infects many Prunus genera [2]. Genetically engineering Prunus domestica with a constitutively expressed coat protein gene (CP) from $P P V$ resulted in lines that highly expressed CP to those that do not express CP gene [3]. One of the two lines that do not transcribe CP RNA nor accumulate CP, is resistant (C5 clone) and the other susceptible (C6 clone) [3,4]. C-6 plum which harbors the full-length CP gene construct, shows some alteration in the CaMV35S promoter and the GUS cassette. This clone has been shown to be highly susceptible to PPV with no evidence of a silencing mechanism [4]. C5 clone, now known as HoneySweet is the sole clone resistant to $P P V$ infection [3,4]. It is not just the absence of expression while the gene is present as in C6 plum that makes the plant resistant to $P P V$. It must be something about the structure of the insertion event. A high diversity of research was developed to better understand the relationship between the virus sequence transgene introduced in the HoneySweet plum and the high level of resistance phenotype of the clone [5-7]. The recent publication of the whole genome sequencing of plum and the insertion events of HoneySweet [8] demonstrated that a multiple viral transgene copy has 
been introduced into the plum genome. These new findings based on these results clarified remarkably the relationship between the number of transgene copy and virus resistance. One of the two insertion events in HoneySweet is designated "insertion event 2" [8] which consists of two inverted repeats of the $P P V \mathrm{CP}$ gene split by a hairpin and is potentially the key to the resistance. The $132 \mathrm{bp}$ of the $3^{\prime}$ untranslated sequence and unpaired in the duplication of the $P P V$ sequence, reshapes the hairpin and together they represent the inverse repeat of $\mathrm{CP}$ sequence split by a hairpin (IRSH) gene construct responsible for the $P P V$ resistance $[8,9]$.

Scorza et al. have reengineered it in the BlueByrd (BO70146) [10] plum and have also successfully confirmed through the majority of clones obtained that they were resistant to $P P V$ infection [9] in a two-year greenhouse experiment. In line with silencing [11] as the regulatory phenomenon related to this IRSH PPV CP, extracted from the HoneySweet plum, we wanted to explore here the regulatory phenomenon. By combining the virus transgene resource of the C1738 plum harboring one copy of the IRSH PPV CP and a NPTII marker gene with that of the $\mathrm{C} 2$ clone encoding $\mathrm{CP}$ within two gene markers, GUS and NPTII [3]. Epigenetics is among a eukaryotic process that is not deeply investigated in woody plants [12]. Although the approach based onto the gene regulation related to the plant development has been exploited [13]. The reported data about the transgene flow from HoneySweet indicated, excepted the species criteria, that in theory, there is no any special barriers about the natural cross between Prunus species [14]. Undoubtedly, the facets of epigenetics are not negligible, when depicted as an uncontrolled variation of genes that express under the pressure of diverse types of environmental factors (abiotic or biotic stress, growth inhibition, etc.) [15].

For the above reasons, controlled studies based onto the assessment of the genetic and phenotypic differences related to the structure and the gene for gene interference of these viral genes were examined here [3,9]. Directed cross hybridization between the two clones, $\mathrm{C} 2$ and $\mathrm{C} 1738$ clones, was attempted in order to study the silencing mechanisms occurring and to decipher the epigenetic phenomenon in action, as well as developing tools and methodology to understand the genetic involvement of the PPV CP sequences. Four hybrid seedlings harboring both the encoding transgene $\mathrm{CP}$ and the IRSH construct were selected. Similar to the transgenic Honeysweet plum, the IRSH harbored by the four hybrid plums silenced the encoding $\mathrm{CP}$ gene. Another hybridization with the conventional BlueByrd (BO70146) plum allowed us to demonstrate that the IRSH without the intact CP generates hybrid resistant clones. Taken together these results, the serendipitous hairpin $\mathrm{CP}$ structure discovered in Prunus represents, first an original genetic tool to better understand the epigenetic phenomenon in perennial trees, and secondly, it reflects a sustainable source of resistance gene to $P P V$ infection.

\section{Materials and Methods}

\subsection{BlueByrd (BO70146) Plum, GF-305 Peach and Virus Resistance}

BlueByrd cv.plum, and GF-305 peach were used in high containment greenhouse assays as positive controls for $P P V$ infection. In order to test plant resistance, each clone was, first, propagated onto the susceptible rootstock Prunus marianna (GF8.1) in a high containment greenhouse (agreement for the use of genetically modified organisms, GMO, for research and development, number 2000, 28 October 2015, Ministry of Education and Research). Since an available number of replicates (3-6 copies) was obtained, plants were graft-inoculated prior to their transfer in cold for setting up an artificial dormancy. $P P V-\mathrm{M}$ was chosen to infect the clones because it causes more severe disease [4-6,16,17]. Initial testing for infection was based on experimental evidence for $P P V$ infection through the appearance of symptoms (mosaic on BlueByrd plum and typical leaf distortion on peach) from 4 weeks after the first bud-break. In light of the virus spread in scions, DAS-ELISA was also used to ensure that the tested trees were successfully infected by the challenger $P P V[18,19]$. Specific polyclonal antibodies raised to PPV (LCA, La Rochelle, France) were used according to the manufacturer's recommendations. All assays were validated at the 
same time with infected GF.8.1 rootstocks. Infection was both recorded through symptom evaluation and an OD value from the DAS-ELISA higher than 0.1 (OD value read at $405 \mathrm{~nm}$ using phosphate buffered saline-Tween as the background value). Following the third cycle of dormancy, molecular detection with RT-PCR confirmed the infection status. OneStep RT-PCR was used to detect PPV RNA. $1 \mu \mathrm{g}$ of total RNA was used in a reagent mixture of $50 \mu \mathrm{L}$ containing buffer, dNTPs, $1 \mathrm{U}$ of mixed enzyme (RTase, Taq DNA polymerase) (Qiagen-Kit, Valencia, Hilden, Germany) and $1 \mu \mathrm{L}$ of the following primers, YGAP (YGAKGABATGTACATTCC) and RB8740 (TCCGGATCCGTTGTTGCTGGMGTGAAAATGGGGTTG) according to [16]. The reaction consisted of an incubation of $30 \mathrm{~min}$ at $50{ }^{\circ} \mathrm{C}$ followed by a denaturing step at $95^{\circ} \mathrm{C}$ during $15 \mathrm{~min}$. PCR was performed with 40 cycles of denaturing at $95^{\circ} \mathrm{C}$ for $30 \mathrm{~s}, 50{ }^{\circ} \mathrm{C}$ for $30 \mathrm{~s}, 72^{\circ} \mathrm{C}$ for $1 \mathrm{~min}$ and a final extension at $72{ }^{\circ} \mathrm{C}$, for $10 \mathrm{~min}$. Because the IRSH construct does not span to the Nib (Nuclear Inclusion b) cistron of PPV RNA, separate PCR reaction forming an amplicon of $460 \mathrm{bp}$ spanning the $\mathrm{COOH}$ part of the $P P V-\mathrm{Nib}$ cistron and $\mathrm{NH} 2$ of the $\mathrm{CP}$ gene was used to detect the ongoing spread of $P P V$.

\subsection{Transformed Plums C1738}

The IRSH construct was isolated from the resistant HoneySweet plum as previously described [9]. It had been cloned into the pBINPLUS / ARS vector (Figure 1a), and hypocotyl slices of BlueByrd (BO70146) cv plum [10] were co-inoculated with the Agrobacterium tumefaciens containing the construct resulting in the C1738 plum used in this study [9].

\subsection{Hybridization}

All respective male progenitors were hand-emasculated. Over the next 2-3 days, pollen was applied on pistils with a brush. Two trials of hybridization were performed, first C2 $\times$ C1738 and C1738 $\times$ C2 and second BlueByrd $\times$ C1738 and C1738 $\times$ BlueByrd.

\subsection{Hybrid Selection via GUS Assays}

Young leaves from hybrid clones were cut and shaped in a small square that were introduced in an eppendorf tube of $1.5 \mathrm{~mL}$. They were soaked in $500 \mu \mathrm{L}$ of $50 \mathrm{mM} \mathrm{Na}_{2} \mathrm{HPO}_{4}$, $\mathrm{pH} 7.0$ and $0.1 \%$ Triton X-100 containing the chromogenic X-Gluc (5-bromo-4-choloro-3indolyl) $\beta$-D-glucuronic acid substrate, overnight at $37^{\circ} \mathrm{C}$. After pipetting the substrate, leaves were bleached by washing with $70 \%$ ethanol that led to the fixation of the blue color revealing the positive assay of GUS [20].

\subsection{Methylation of Transgene}

Plant genomic DNA of studied clones were extracted according to $[16,17,21]$. In total, $2 \mu \mathrm{g}$ of DNA were digested overnight in parallel, with $\mathrm{BfuCI}$ and the isoschizomer $\mathrm{MboI}$ at $37^{\circ} \mathrm{C}$. After a precontrol of the digestion efficiency, one aliquote $(1 / 10)$ of the digested DNA was amplified by PCR using the couple of primers $340 \mathrm{Fw}$ and $660 \mathrm{Rev}$ according to $[16,17,22]$. PCR conditions were one cycle of $94^{\circ} \mathrm{C}, 2 \mathrm{~min}, 40$ cycles of $94{ }^{\circ} \mathrm{C}, 30 \mathrm{~s}, 55^{\circ} \mathrm{C}$, $30 \mathrm{~s}, 72{ }^{\circ} \mathrm{C}, 1 \mathrm{~min}$, followed by one cycle of $72{ }^{\circ} \mathrm{C}$ for $10 \mathrm{~min}$ prior to stop at $12{ }^{\circ} \mathrm{C}$. In total, $1 \mathrm{~Kb}$ DNA weight marker (Invitrogen, Thermo Fisher Scientific, Waltham, MA, USA), an aliquot of the amplified DNA was fractionated onto a $2.5 \%$ agarose gel electrophoresis. The occurrence of an amplicon of $425 \mathrm{bp}$ symbolized that the template is methylated.

\section{6. siRNA Detection}

Total RNAs were extracted according to $[16,17,22,23] .30 \mu \mathrm{g}$ of the total RNA were loaded on $16 \%$ of a denaturing urea-PAGE. Electrophoresis was carried out at $25 \mathrm{~mA}$ with 0.5 TBE. during 6hours. Following to an electroblotting transfer with 0.5 TBE, in cold (at $4{ }^{\circ} \mathrm{C}$ ) onto the NX membrane, (GE Healthcare, Buckinghamshire, UK), siRNAs were probed with a labeled $\alpha^{32} \mathrm{P}$ dCTP-PPV CP amplicon probe. 


\subsection{Production of a Labeled ${ }^{32}$ P PPV CP Probe}

To detect the PPV CP sequence either introduced or transcribed in plum genome, the use of a ${ }^{32} \mathrm{P}$ molecular probe is among the specific and reproducible system [16,17]. By PCR-amplifying the PPV CP sequence, we used, as template, the pGA482GG/PPVCP-33 recombinant plasmid [3] in a reagent mixture of $50 \mu \mathrm{L}$ containing buffer, dATP, dGTP, dTTP and, $\alpha{ }^{32} \mathrm{P}$ dCTP (Perkin Elmer, Waltham, MA, USA), 1U Taq DNA polymerase (Qiagen-Kit, Valencia, Hilden, Germany) with forward primer (CPFwd: AAGCTGACGAAAGACAGGACGAG) and reverse primer (RevCP: CTACACTCCCCTCACACCGAGGAA). The conditions of the PCR were as follows: denaturation at $94{ }^{\circ} \mathrm{C}$, for $2 \mathrm{~min}, 40$ cycles of denaturaion at $94{ }^{\circ} \mathrm{C}$ for $1 \mathrm{~min}$, annealing at $55^{\circ} \mathrm{C}$ for $1 \mathrm{~min}$, amplification at $72{ }^{\circ} \mathrm{C}$ for 1 min and final extension at $72{ }^{\circ} \mathrm{C}$ for $10 \mathrm{~min}$. Prior to use, the labeled ${ }^{32} \mathrm{P} P P V \mathrm{CP}$ probe was purified through a size-exclusion MicroSpin G25 column (Amersham, GE Healthcare, Buckinghamshire, UK).

\subsection{Western-Blotting Assays}

In order to serologically detect any viral protein, the high specificity of the antisera is among the determinant criterion. Specific antisera to $P P V$ were produced from the intra-muscular injection of purified $P P V$ to rabbits (INRAe-Bordeaux). To perform the detection of the PPV CP in plum tissue, total soluble proteins were extracted from young leaves in a lysis buffer according to [4]. $300 \mu \mathrm{g}$ of total soluble proteins were fractionated by $12 \%$ SDS-Polyacrylamide gel electrophoresis (PAGE). Proteins were electrotransferred onto a nitrocellulose membrane blot and probed with a rabbit polyclonal antibody against $P P V$ (INRAe-Bordeaux) [4]. The reaction was revealed with anti-rabbit (goat) secondary antibodies coupled to phosphatase alkaline (goat anti-rabbit, Jackson, ImmunoResearch, West Grove, PA, USA). Chromogenic immunodetection was done with NBT/BCIP colored substrate (Sigma Aldrich, Saint-Louis, MI, USA). The expected band, a protein of $36 \mathrm{KDa}$ was followed with a pre-stained molecular weight marker (Invitrogen, Gaithersburg, MD, USA).

\section{Results}

\subsection{Transgenic C1738 and D1738 Clones}

Two clones containing the IRSH construct (Figure 1a) previously characterized by Scorza et al. [9] C1738 and D1738 clone, were further characterized. D1738 plum is among the 18 clones characterized by Scorza et al. [9]. It had been shown to be resistant [9] and is used a reference. However, the development of the C1738 clone, likely harboring one transgene copy (Figure 1b), was delayed. Similarly, to the HoneySweet plum, all clones harboring the IRSH were expected to accumulate siRNA related to the CP (Figure 1c). In order to assess the behavior of this clone to $P P V$ infection, C1738 clone was replicated by grafting onto the P. marianna GF 8.1 rootstocks. Six plant replicates were challenged to PPV infection. PPV detection in rootstocks was crucial for indicating that scions are infected, At least three to four dormancy cycles were regarded as reliable to record the $P P V$ spread in whole plants $[4,16,17]$. Once $P P V$ moved from the rootstock to the scion $[4,7,16-19], P P V$ is detectable in any susceptible hosts, from the fourth week following to the bud-break of the first dormancy cycle. From the fourth cycle of dormancy (Figure 1d: E raw: 17 September 2015), infected rootstocks differed from the resistant scions. Through either the appearance of symptoms in rootstocks (not shown) or/and the analytical detection of $P P V$ carried out in laboratory, positive DAS-ELISA in the rootstocks, ensured that the tested trees were under pressure from the challenger $P P V$ (Figure 1d) $[4,7,16-18,22,23]$. Histograms that represent the relative levels of $P P V$ infection in the rootstock section are opposed to those of the $\mathrm{C} 1738$ scions. Not one $\mathrm{C} 1738$ plant was infected as indicated by DAS-ELISA readings. These studies were confirmed after carrying out total RNA extraction and RT/PCR analyses. Interestingly, no PPV RNA was detected in the C1738 scion (not shown). These results suggested that like D1738, C1738 is highly resistant plant to $P P V$ infection (Figure 1d). 


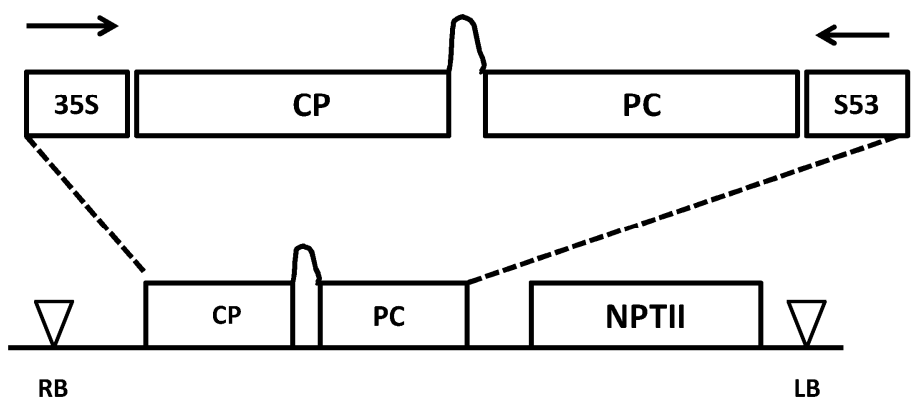

(a)

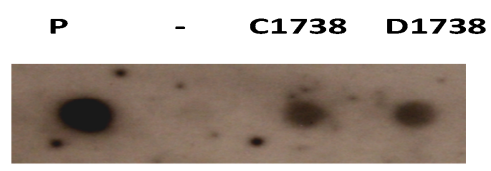

(b)

siRNA accumulated in plum-trees

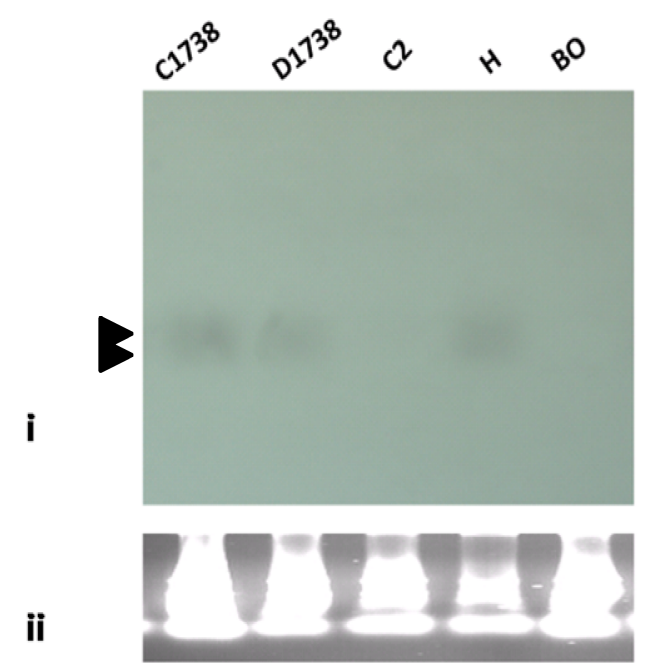

(c)

Figure 1. Cont. 


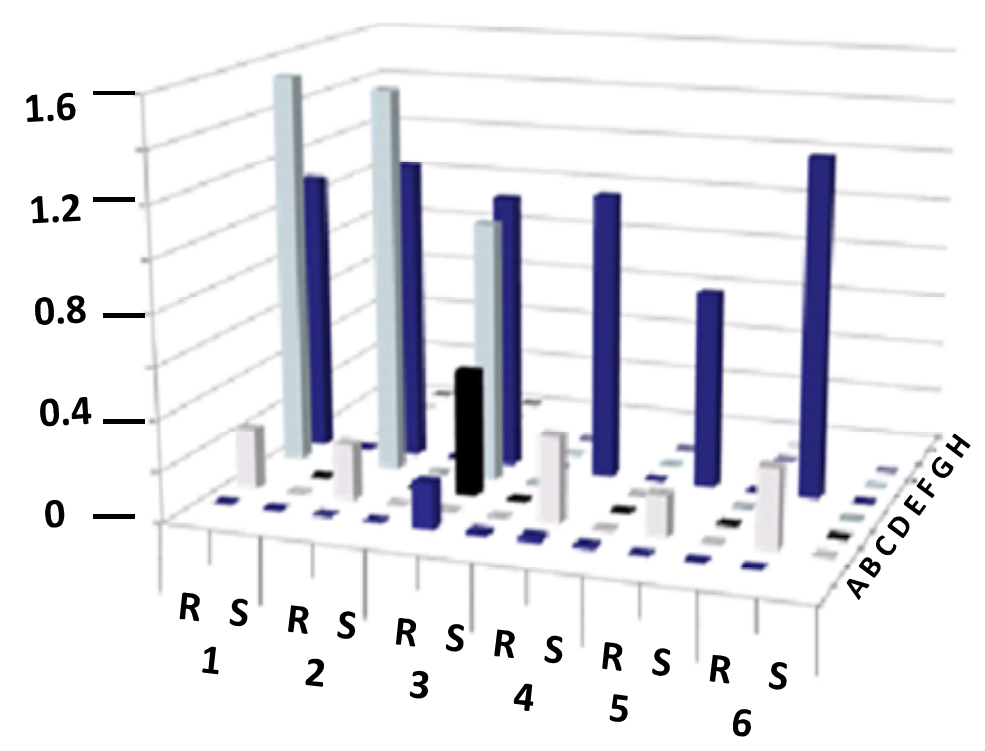

(d)

Figure 1. $P P V$ resistance of C1738 plum. (a) Schematic diagram of the T-DNA of the recombinant pBINPLUS/ARS-IRSH construct (RB: Right border, LB: left border). (b) Dot-blotting of plant DNA for checking the homologous copy number of C1738 and D1738 plums. P, recombinant PPV CP plasmid, (-) no DNA, C: C1738 clone, D: D1738. clone. (c) (i) Northern blot analysis of the siRNA accumulated in the non-infected plums including C1738, D1738, C2, H: HoneySweet and BO: BlueByrd plums. Arrowheads in the left margin indicate the siRNA doublet (21 and $24 \mathrm{nt}$ ) bands detected with the labeled $\alpha{ }^{32} \mathrm{P}$ dCTP-PPV CP amplicon probe. (ii) Ribosomal RNA control. (d) Behavior of the C1738 clone over 4 dormancy cycles: Histograms representing the average of different OD values of DAS-ELISA tests (scale bar) from leaves sampled from 6 plant replicates at different dates A raw: 25 July 2012, first dormancy cycle, B raw: 4 April 2013, second dormancy cycle C: 14 May 2013, D raw: 4 November 2014, third dormancy cycle, E raw: 17 September 2015, fourth dormancy cycle, F: 12 January 2016, G raw: 20 July 2016, fifth dormancy cycle, H: 4 October 2016 following to the bud-breaking date (A, B, D, E and G raws) (indicated at the right). Printed R, leaves collected from the GF-8.1 rootstocks, and S, those from the transgenic shoots.

\subsection{Cross Hybridization between the Hexaploid C-2 and C-1738 Clones}

To understand the silencing mechanisms related with the IRSH construct, C1738 plum and $\mathrm{C} 2$, the plum clone harboring the expressed transgene $\mathrm{CP}$, were hybridized. Following to the prerequisite emasculation, respectively, of the flowers of $\mathrm{C}-2$ clone and those of C-1738 plum (Figure 2a) for reciprocal crosses, dried and lyophilized pollens from each of the clones were, respectively, applied onto the pistils. More than 70 fruit were collected from the $\mathrm{C} 2 \times \mathrm{C} 1738$ hybridization, however less than 10 fruit were obtained with C1738 $\times$ C2 (Table 1). Embryos were pre-incubated in the cold room prior to their move to growth chamber. Following to the acclimation of rooted seedlings in greenhouse, leaves were collected and were tested for GUS [20] indicating the presence of the expressed transgene $\mathrm{CP}$ initially introduced in $\mathrm{C} 2$ clone. A few hybrids did not develop, so Table 1 summarizes the results about 63 plants. As example, Figure $2 \mathrm{~b}$ shows that the genetic cross $\mathrm{C} 2 \times \mathrm{C} 1738$ gave 32/60 transgenic hybrid clones. A ratio that matches to the Mendelian rules as we have already observed with cross hybridization between "HoneySweet" plum and, respectively, the conventional plums, Ente 303 and Quetsche 2906 [24]. Only one of the 3 hybrid clones from the cross hybridization with C1738 $\times$ C2.was positive for GUS expression. 

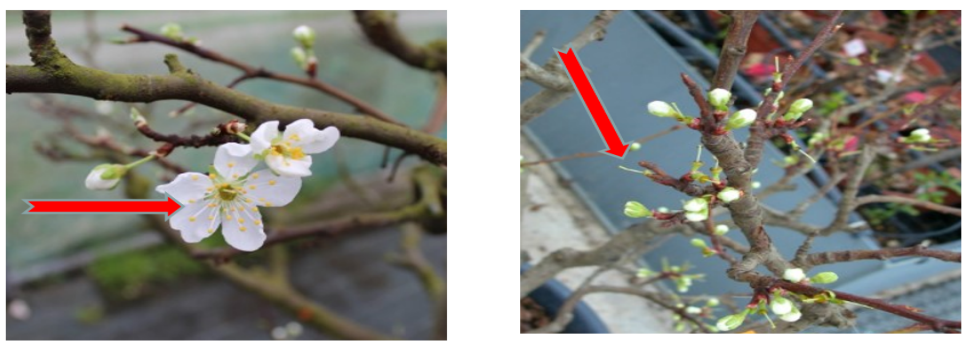

(a)
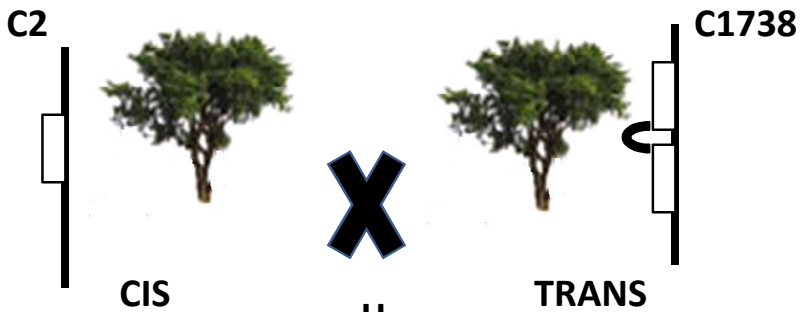

$4 \mid$

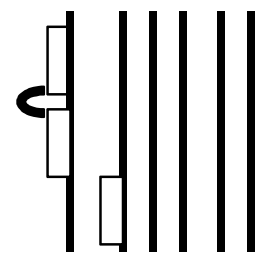

(b)

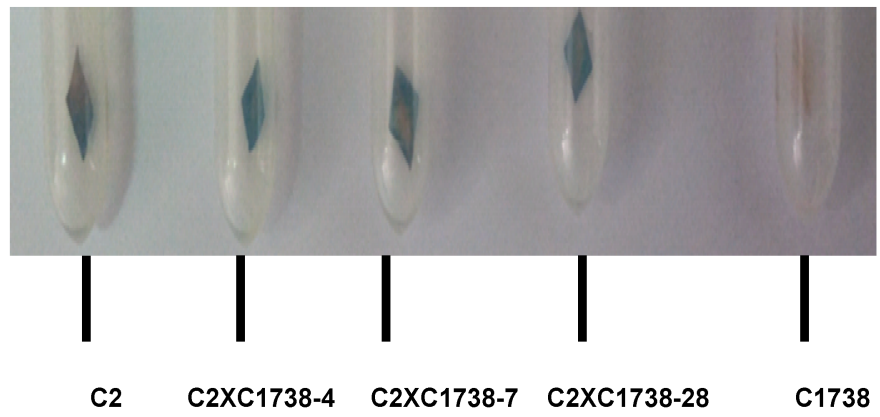

(c)

Figure 2. Hybridization of $\mathrm{C} 2$ and C1738. (a) From left to right: intact and emasculated flowers of clone C1738; (b) Scheme of the cross-hybridization between C2 and C1738 clones; (c) Histochemical analysis of GUS activity in small leaves sampled from the two parental clones, C2 and C1738 and 3 $\mathrm{C} 2 \times \mathrm{C} 1738$ hybrids.

Table 1. Hybrid clones harboring both a methylated CP transgene and positive GUS.

\begin{tabular}{cccc}
\hline Cross Hybridization & Rooted Plants & Positive Gus Assays & Methylated cp and Positive Gus \\
\hline C1738 $\times$ C2 & 3 & $1 / 3$ & $0 / 1$ \\
C $2 \times$ C1738 & 60 & $32 / 60$ & $4 / 32$ \\
TOTAL & 63 & $33 / 63$ & $4 / 33$
\end{tabular}




\subsection{Inhibition of the CP Gene Expressed in C-2 Clone}

\subsubsection{Heritable Epigenetics}

In line with the regulatory mechanism related with epigenetics such as methylation [7, $16,17,22,23,25]$, molecular analysis of the transgene CP from the 33 hybrid clones was studied (Table 1). Leaves were collected and the plant DNA extracted. A coupling reaction related to the over-digestion of the genomic DNA with $B F u C I$ restriction enzyme that can cut at the 2 GATC sites of the CP transgene only if the sites are not methylated. If the sites are methylated then by the subsequent PCR-reaction using two primers flanking the 2 sites, an amplicon of $425 \mathrm{bp}$ is present. Surprisingly, only $4 / 33$ clones that express GUS (Figure $2 b$ ) showed a methylated transgene (Figure $3 b$ ).

To conclude, from the genetic cross $\mathrm{C} 2 \times \mathrm{C} 1738,28 / 60$ of hybrid clones had no evidence of methylation indicative of silencing, 32 clones harbor the transgene $\mathrm{CP}$ of $\mathrm{C} 2$ clone and amidst the 32 clones only four clones have evidence of methylation and probably harbor the two transgenic events (Table 1). The inheritance of methylation has frequently occurred in eukaryotic systems, and these viral origin genes are no different $[12,13,16,17$, 22,24]. It appears to be methylated regardless of whether or not the insertion of the viral genes in one locus (cis position) or their split in two different loci (trans position), where four hybrid clones were identified; C-2 $\times$ C-1738-4, $-7,-28$ and -37 hybrids (Figure 3). To conclude, from the genetic cross $\mathrm{C} 2 \times \mathrm{C} 1738,28 / 60$ of hybrid clones were not methylated and probably did not carry the IRSH, 28 clones harbor the transgene $\mathrm{CP}$ of $\mathrm{C} 2$ clone and only four clones harbor the two targeted events (Table 1).

\subsubsection{Western-Blotting Assays}

In order to confirm the potential silencing of the $\mathrm{CP}$ resulting in lowered expression by the four clones, that are both positive for GUS and the methylated transgene, a protein study to determine if the PPV CP gene was affected. This would then measure the targeted phenomenon confirming the efficient of the IRSH CP gene cassette to silence the CP gene belonging to the parental $\mathrm{C}-2$ clone. Total soluble proteins from different clones including the four C-2 $\times$ C-1738-4, -7, -28 and -37 hybrids were assayed through western-blotting experiments. Figure $3 \mathrm{c}$ shows that these four clones possessing the methylated transgene do not accumulate CP. In parallel, hybrid clones used as control, known as harboring an unmethylated CP gene, C-2 $\times$ C-1738-6 and -63, chosen as similar control to the parental $\mathrm{C} 2$ clone both express the $\mathrm{CP}$ gene [3]. Similarly, the sole C-1738 $\times$ C2-13 hybrid clone, that showed a positive GUS assay and harbors an unmethylated DNA, was confirmed by the immunoblot had detectable CP. Silencing was based on the methylation mechanism impacted by the modified transcription of the $P P V \mathrm{CP}$ gene originated from clone $\mathrm{C} 2$. There is evidence here that the RNA-based silencing results from the homologous methylated gene co-integrated in planta. 


\section{HYBRIDS}

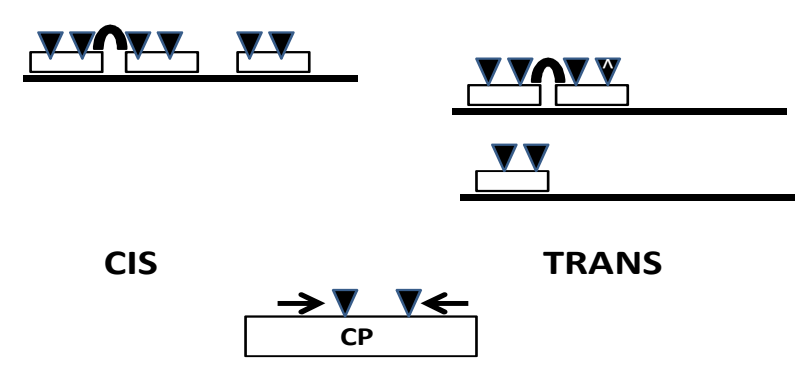

(a)

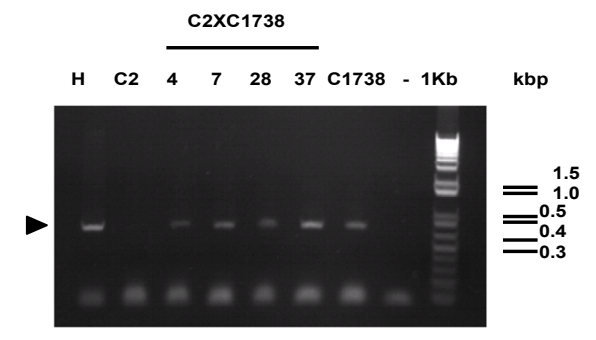

(b)

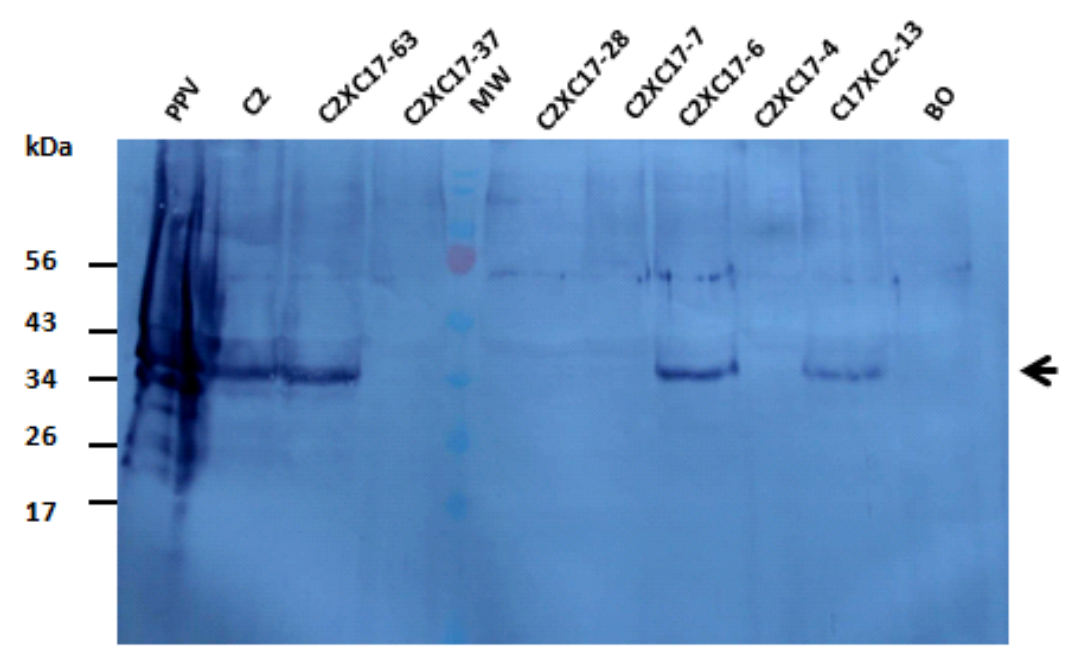

(c)

Figure 3. (a) Scheme of the PPV CP transgene integrated either in Cis- and Trans-position in hybrid plums: Vertical arrowheads indicate the position of the targeted GATC restriction sites flanked by the primer pair, $340 \mathrm{Fwd}$ and $660 \mathrm{Rev}$ (arrows) used in PCR reaction. (b) Agarose gel analysis (2.5\%) of amplicon (arrowhead in the left margin) from the over digested DNA of the different plants, from left to right, lanes: $\mathrm{H}$, HoneySweet plum (as positive control), $\mathrm{C} 2$ : cloneC2, $\mathrm{C} 2 \times \mathrm{C} 1738$ hybrid clones (4, 7, 28, 37), C1738, (-), no DNA, 1 kb markers (Invitrogen, Gaithersburg, MD, USA). (c) Immunoblotting of total protein extracts from plum leaves (left to right): $P P V$-infected Bluebyrd $\mathrm{BO}$, used as positive control, C2, C2 × C1738 63, C2 × C1738-37 hybrids, pre-stained MW (Invitrogen, Gaithersburg, MD, USA), C2 × C1738-28, C2 × C1738-7, C2 × C1738-6, C2 × C1738-4, C1738 × C2-13 hybrids and virus-free Bluebyrd BO, used as negative control. Arrow in the right margin represents the expected PPV CP. 


\subsection{Inheritability of PPV Resistance in Hybrid Clones of BO146xC-1738 Clone}

As previously shown, cross-hybridization enables the IRSH transfer. Since the identification of the hybrid clones, the occurrence of the methylated transgene was verified. Through the cross-hybridization with the conventional Bluebyrd, already characterized as highly susceptible to $P P V[4,7,15-19,23]$, a lot of hybrid clones were obtained $(11 / 30)$ of the faster growing clones were propagated onto P. marianna GF 8.1 rootstock. Figure 4 shows the relevant efficiency of IRSH as measured by DAS-ELISA values following infection.

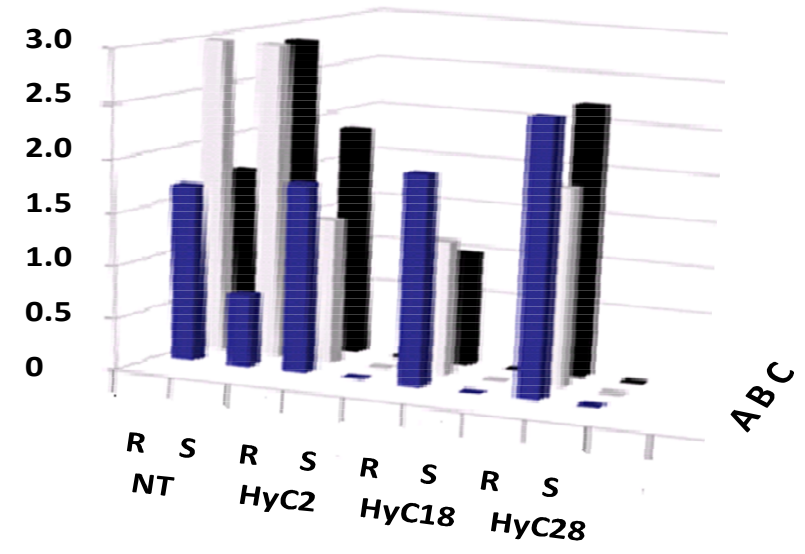

Figure 4. Histograms representing the average of the different OD values of DAS-ELISA tests (scale bar) from leaves sampled from 5 plant replicates performed at different bud-breaking period, blue: A, cycle 1, grey: B, cycle 2 and black: C, cycle 3. NT, non-transformed BlueByrd BO70146 and BlueByrd BO70146 × C1738 hybrids including HybC1738-2 (HyC2), -18 (HyC18), 28 (HyC28). R, graphs of leaves sampled from the P. marianna GF-8.1 rootstocks, and S, those from the transgenic shoots.

All three hybrids tested including Bluebyrd BO70146 × C1738-2 (HyC2), -18 (HyC18), -28 (HyC28) behaved similarly to the parental C1738 plum ((Figure 1d). There is an evidence that, the transgenic scion (S) had negligible value compared to the relative amount of $P P V$ in non-transgenic Bluebyrd BO70146 (NT) and susceptible P. marianna GF-8.1 rootstock (R), shown to be susceptible from the first dormancy cycle (blue bar graphs in A raw). To gain an understanding of the plant phenotypes, the occurrence solely of symptoms in control (NT plants and rootstocks, R) (not shown) allows the confirmation of diseased trees. Here we present the data of the serological assays depicting the challenging assays to $P P V$ infection following three cycles of dormancy (A, B and C raws) reflecting the natural time for increased viral loads. Based on the sampling of leaves of tested plants including the conventional BO70146 plum (NT) and the different replicates of the three selected hybrid clones ( $\mathrm{HyC} 2, \mathrm{HyC} 18$ and $\mathrm{HyC} 28)$, the histograms represent an average OD values of the five plant replicates of each clone. Based on the homologous data of the serological studies, these selected hybrid clones are highly resistant. Genetic transfer of the IRSH construct has been successfully established. Expectedly, RNAi produced from the dsRNA transcribed from the two CaMV35S promoter can be inherited from one locus and expressed as a resistance trait such as a haploid parent, similar to the HoneySweet plum, source of the IRSH construct $[5,6,8,9,23]$.

\section{Discussion}

These studies showed that the bidirectional promoters flanking the two inverted repeats of $P P V \mathrm{CP}$ gene functioned in the new background as they had in the original HoneySweet $[8,9]$. The IRSH structure was efficiently transcribed by the RNA polymerase II in nuclei [26] prior to the sequential transfer of the silencing in cytoplasm. Epigenetics is among eukaryotic processes that regulate plant development (growth, flowering, fruit development etc.) as well as under environmental pressure [12-14,18,19,25]. Briefly, cell differentiation is associated with phenotypic changes [27]. Hily et al. [25] showed that the 
transgene PPV CP in the resistant HoneySweet has a high level of methylation and that is re-set in progeny carrying the transgenes [25]. Among the possible co-affected sequences with a low level of methylation, was the CaMV35S promoter [25]. In order to decipher this related silencing with CaMV35S promoter, the hypothesis was a prerequisite that each clone harbors one copy of the virus transgene as a haploid character. Four clones harboring the transgene $\mathrm{CP}$, from the high $\mathrm{CP}$ expression parent, clone $\mathrm{C} 2$ and the IRSH of the C1738 clone resulted in a silenced CP gene. The associated activities, the chromogenic GUS expression from the C2 parent and the transgene methylation related with the IRSH construct, the present studies provided rational support that the CaMV35S promoter, possibly regulated through the histone modification, did not have any large effect on methylation because it also drives the marker GUS expression (Figure 2). Although the silencing mechanisms that led to a phenotypic variation based onto the knock down of the transgene CP in the 4 hybrid clones is related to an epigenetic pattern [13]. Figure 3a,b show that an epigenetic regulation, based on the methylation of the transgene $\mathrm{CP}$, can occur in the nuclei. There is some evidence that the histone modification led to the inhibition of the activity of the transcription machinery.

As analytical consequences were the methylation of the transgene $\mathrm{CP}$ from $\mathrm{C} 2$ clone occurred in the four hybrid clones, C-2 $\times$ C-1738-4, -7, -28 and -37 hybrids. The real phenomenon is more a "transcription gene silencing" (TGS) rather a post-transcription gene silencing because no RNA is transcribed [27,28]. All four hybrid clones develop the posttranscriptional gene silencing (PTGS) because they harbor the IRSH construct. Referring to Scorza et al.'s results about nuclear-run on assays [7], there was some level of transcribed RNA from nuclei of HoneySweet plum. The level is not so different to that transcribed by the higher $\mathrm{CP}$ gene expressor clone $\mathrm{C} 4[3,7]$. Consequently, all four hybrid clones, including C-2 × C-1738-4, -7, -28 and -37 that do not accumulate CP, develop two silencing machinery TGS which functions in nuclei and PTGS which is revealed in cytoplasm. Without any change in the engineered PPV CP sequence in plum genome, the methylation status down regulates the $\mathrm{CP}$ gene expression in these hybrid plums. PTGS [28] is related to the transcription of the dsRNA from the IRSH that functions in the cytoplasm in order to be diced into siRNA by the dicer-like-proteins [29]. Similarly, to the HoneySweet plum [5-9,16,17,22,23,27], Figure 1 has shown that siRNA accumulated in the C1738 clone most likely recognizing the viral genome and cleaved it as the normal RNAi defense [11,17,27-30]. In extenso, the Bluebyrd BO70146 × C1738 hybrids (BO70146 $\times$ C1738-2, -18, -28) also support the occurrence of the PTGS to trigger any PPV RNA restrictively replicating in cytoplasm (Figure 4 ).

Regardless of the developmental stage of the hybrid clones, the impact of the methylation phenomenon occurring through the chromatin remodeling at the nuclei compartment is obviously extended in the cytoplasm. In order to study the genetic and phenotypic variation related with the engineered transgene, hybrid clones with the Bluebyrd plum as maternal parent and C1738 as paternal progenitor successfully showed that the IRSH, a serendipitous construct resulting from the re-arranged PPV CP construct in the plum chromosomes is active (Figure 4). This can happen regardless of the configuration, either Cis or Trans of the CP transgene from clone $\mathrm{C} 2$ in the four hybrid (C2xC1738) plum clones. The present study did not precisely identify the orientation but Cis would require them to be on the same chromosome, as in HoneySweet. However, avoiding any speculation, the Cis-element is more powerful. Since Callahan et al. [8] indicated that the known hybrid clones rated from the Mendelian fashion might segregate as a diploid character. This is interesting for breeding any hexaploid P. domestica species. Would that really mean that any cross-hybridization with European plum could arguably stand in that way? Unfortunately, the use of the IRSH clone as maternal progenitor gave a poor ratio of hybrid clones. Here, in Europe, the asynchrony flowering of the C-1738 plum clone is among the detrimental cause. Here we showed that the TGS and the PTGS can occur in perennials, both phenomena related with the homology dependent RNA sequencing are suitably active in the two compartment cells. Two major enzymes actively support the silencing mechanism in plum. 
First, the RNA polymerase II [26,30] that transcribes the dsRNA from the IRSH template in both directions. Secondly, the 24nt siRNA resulting from either the DNA dependent RNA polymerase IV or the tasiRNA (trans-acting RNAi) interacting with the RNA dependent RNA polymerase VI (RDR6) moving as guide to induce the methylation of the homologous DNA sequence $[16,17,29]$.

Expectedly hybrid clones obtained from the cross hybridization between the conventional BlueByrd B70146 plum and C-1738 confirmed the efficient transfer of the IRHS virus gene. Hybrid clones that inherited the IRSH CP successfully silenced the PPV genome (Figure 4). These studies compared with the initial use of the IRSH associated with other pieces of PPV CP sequences in the HoneySweet plum [8] elucidate two additive information. First the cross hybridization in any hexaploid hybrid clones is likely inherited with any use of a gene that segregates as a diploid. Second, the epigenetic phenomenon provides evidence about how and where the invading PPV genome started to be degraded by the AGO-plant RNasesIII enzyme [26-28,30]. Although some definitive experiments were not done, obviously the annealing of the complementary siRNA sequence to the $3^{\prime}$ terminal region of $P P V$ genome should serve as template to the endonuclease RNase type III [28-30]. Avoiding speculation about the following step, the unprotected diced mRNA should be processed according to the siRNA pathways that led to the complete degradation of PPV RNA. While the one group of the AGO proteins is preferentially guided by the 24nt-siRNA to induce the transcriptional gene silencing, the second group of AGOs guided by the 21nt-siRNA contribute to the achievement of the PTGS. TGS and PTGS occurring, first in nuclei, inhibit any homologous sequenced RNA $[28,30]$. This was the scenario in hybrid C-2 $\times$ C-1738-4, $-7,-28$ and -37 that do not express CP gene. Transferred in the cytoplasm, these siRNAs trigger the homologous RNA sequence occurring. In short, PPV genome introduced by any means (naturally by viruliferous aphids or artificially by infected graft) $[4-7,15-18,21-25,29]$ that starts to be replicated with the viral genome machinery, is specifically triggered by these siRNAs. When systemically spread in the whole plant these siRNAs led to the PPV RNA degradation [16,17,22,23,29]. Under conditions of mixed infection including either Prune dwarf virus (PDV) or Prunus necrotic ringspot virus, (PNRSV), RNA-silencing derived resistance to $P P V$ remains stable. Disregard to the synergistic interactions possibly occurring between viruses, the degradation of PPV RNA is related to the homology-dependent RNA silencing [31-33].

Although the present study was performed under high containment greenhouse conditions, the robustness of the silencing induced by IRSH PPV CP harbored by the HoneySweet plum in natural conditions $[18,19,32,33]$ is one obvious reason for using biotechnology against virus. Long term field trials clearly demonstrated that regardless of different ecological conditions (variable climate, aphid vectors, virus pressure, different strains etc.) in four PPV endemic areas from Poland, Spain, Romania and Czech Republic, the IRSH rearrangement in "HoneySweet" led to the setting up of a high and durable resistance to natural $P P V$ infection $[18,19,25,32,33]$.

\section{Conclusions}

The rearranged IRSH construct extracted from the HoneySweet plum is a powerful tool to accurately produce a dsRNA that triggers any homologous dependent sequence co-introduced and, in extenso, the incoming virus infection. Through the epigenetic phenomenon that occurred in progeny, the transgene construct strongly silences either any co-integrated CP gene or any incoming PPV RNA in trees with the IRSH construct. These silencing studies gave more accuracy about the two phenomena that occurred, first in nuclei (TGS) and secondly in cytoplasm (PTGS). Subsequently, evidence to degrade the $P P V$ RNA from its $3^{\prime}$ terminal region strongly supports the sequential cleavage of the virus genome. These studies reflect a successful control strategy about the robust phenotype displayed by HoneySweet plum that is sharing a stable and durable resistance to PPV infection in field natural conditions. 
Author Contributions: M.R. conceived the hypothesis and drew the work plan. R.S. produced the conventional BlueByrd BO70146 plum and the transgenic C- and D-1738 plums. 70\% of all experiments have been performed by P.B. The rest was done and analyzed by M.R. with the other cooperators R.S., A.C., C.D. and J.K.K. (2011-2016) under the EU-FP7 Interest Contract number 269292, involving France, Czech Republic and USA. M.R. and I.Z. have also exchanged data under the framework Brancusi, a binational cooperation between France and Romania (2013-2014). M.R., A.C., I.Z. and J.K.K. wrote the manuscript. All authors have read and agreed to the published version of the manuscript.

Funding: This article/publication is based upon work from COST Action iPlanta, supported by COST (European Cooperation in Science and Technology), www.cost.eu (accessed on October 2016April 2021). We are grateful to Mezzetti (Univ. of Ancone, Italy) who coordinated iPlanta (October 2016-April 2021) and followed up the progress achieved in this framework involving M.R., I.Z. and J.K.K.

Institutional Review Board Statement: All experiments were processed according to the agreement for the use of genetically modified organisms, GMO, for research and development, number 2000, 28 October 2015, French Ministry of Education and Research.

Informed Consent Statement: Not appropriate.

Data Availability Statement: Not appropriate.

Acknowledgments: We are also grateful to Mark Demuth (USDA) for taking care and sending plants. Thierry Mauduit, who is managing every day, the suitable parameters to maintain the high containment greenhouse conditions at INRAe-Bordeaux (France).

Conflicts of Interest: The authors declare that there is no conflict of interest.

\section{References}

1. Abel, P.P.; Nelson, R.R.; de, B.; Hoffmann, N.; Rogers, S.G.; Fraley, R.T.; Beachy, R.H. Delay of disease development in transgenic plants that express the tobacco mosaic virus coat protein gene. Science 1986, 232, 738-743. [CrossRef] [PubMed]

2. Atanassov, D. Plum pox. A new virus disease. Ann. Univ. Sofia Fac. Agric. Silvic. 1932, 11, 49-69.

3. Scorza, R.; Ravelonandro, M.; Callahan, A.M.; Cordts, J.M.; Fuchs, M.; Dunez, J.; Gonsalves, D. Transgenic Plums (Prunus-domestica L.) Express the Plum pox virus Coat Protein Gene. Plant Cell Rep. 1994, 14, 18-22. [CrossRef]

4. Ravelonandro, M.; Scorza, R.; Bachelier, J.C.; Labonne, G.; Levy, L.; Damsteegt, V.; Callahan, A.M.; Dunez, J. Resistance of transgenic Prunus domestica to Plum pox virus infection. Plant Dis. 1997, 81, 1231-1235. [CrossRef]

5. Scorza, R.; Callahan, A.; Dardick, C.; Ravelonandro, M.; Polak, J.; Malinowski, T.; Zagrai, I.; Cambra, M.; Kamenova, I. Genetic engineering of Plum pox virus resistance: 'HoneySweet' plum-From concept to product. Plant Cell Tissue Organ Cult. 2013, 115, 1-12. [CrossRef]

6. Scorza, R.; Ravelonandro, M.; Callahan, A.; Zagrai, I.; Polak, J.; Malinowski, T.; Cambra, M.; Levy, L.; Damsteegt, V.; Krska, B.; et al. HoneySweet'(C5), the first genetically engineered Plum pox virus resistant Plum (Prunus domestica L.) Cultivar. Hortscience 2016, 51, 601-603. [CrossRef]

7. Scorza, R.; Callahan, A.; Levy, L.; Damsteegt, V.; Webb, K.; Ravelonandro, M. Posttranscriptional gene silencing in Plum pox virus resistant transgenic European plum containing the Plum pox potyvirus coat protein gene. Trans. Res. 2001, 1054, 1-9. [CrossRef]

8. Callahan, A.M.; Zhebentyayeva, T.N.; Humann, J.L.; Saski, C.A.; Galimba, K.D.; Georgi, L.L.; Scorza, R.; Main, D.; Dardick, C.D. Defining the 'HoneySweet' insertion event utilizing NextGen sequencing and a de novo genome assembly of plum (Prunus domestica). Hortic. Res. 2021, 8, 8. [CrossRef]

9. Scorza, R.; Georgi, L.; Callahan, A.M.; Petri, C.; Hily, J.; Dardick, C.D.; Damsteegt, V.D.; Ravelonandro, M. Hairpin Plum pox virus coat protein (hpPPV-CP) structure in HoneySweet C5 plum provides PPV resistance when genetically engineered into plum (Prunus domestica) seedlings. Jul. Kühn-Arch. 2010, 427, 141-146.

10. Scorza, R.; Fogle, H.W. Bluebyrd plum. HortScience 1999, 34, 1129-1130. [CrossRef]

11. Baulcombe, D.C. RNA as a target and an initiator of post-transcriptional gene silencing in trangenic plants. Plant Mol. Biol. 1996, 32, 79-88. [CrossRef] [PubMed]

12. Amara, J.J.; Ribeyre, Z.; Vigneaud, J.; Sow, M.D.; Fichot, R.; Messier, C.; Pinto, G.; Nolet, P.; Maury, S. Advances and Promises of Epigenetics for Forest Trees. Forests 2020, 11, 976. [CrossRef]

13. Matzke, M.A.; Mosher, R.A. RNA-directed DNA methylation: An epigenetic pathway of increasing complexity. Nat. Rev. Genet. 2014, 15, 394-408. [CrossRef] [PubMed]

14. Scorza, R.; Jriss, A.B.; Callahan, A.; Webb, K.; Demuth, M.; Gottwald, T. Spatial and Temporal Assessment of Pollen- and Seed-Mediated Gene Flow from Genetically Engineered Plum Prunus domestica. PLoS ONE 2013, 8, e75291. [CrossRef]

15. Grant-Downton, R.T.; Dickinson, H.G. Epigenetics and its Implications for Plant Biology 2. The 'Epigenetic Epiphany': Epigenetics, Evolution and Beyond. Ann. Bot. 2006, 97, 11-27. [CrossRef] 
16. Ravelonandro, M.; Scorza, R.; Hily, J.M.; Briard, P. The efficiency of RNA interference for conferring stable resistance to Plum pox virus. Plant Cell Tissue Organ Cult. 2014, 118, 347-356. [CrossRef]

17. Ravelonandro, M.; Scorza, R.; Briard, P. Innovative RNAi Strategies and Tactics to Tackle Plum pox virus (PPV) Genome in Prunus domestica plum. Plants 2019, 8, 565. [CrossRef]

18. Zagrai, I.; Ravelonandro, M.; Gaboreanu, I.; Ferencz, B.; Scorza, R.; Zagrai, L.; Kelemen, B.; Pamfil, D.; Popescu, O. Transgenic plums expressing Plum pox virus coat protein gene do not affect the PPV strain composition or produce PPV recombinants. $J$. Plant Pathol. 2011, 93, 159-165.

19. Malinowski, T.; Cambra, M.; Capote, N.; Zawadzka, B.; Gorris, M.T.; Scorza, R.; Ravelonandro, M. Field trials of plum clones transformed with the Plum pox virus coat protein (PPV-cp) gene. Plant Dis. 2006, 90, 1012-1018. [CrossRef]

20. Jefferson, R.A.; Kavanagh, T.A.; Bevan, M. GUS fusions: B-glucuronidase as a sensitive and versatile gene. EMBO J. 1987, 6, 3901-3907. [CrossRef]

21. Kobayashi, N.; Horikoshi, T.; Katsuyama, H.; Handa, T.; Takayanagi, K. A simple and efficient DNA extraction method for plants, especially woody plants. Plant Tissue Cult. Biotechnol. 1998, 4, 76-80.

22. Kundu, J.K.; Briard, P.; Hily, J.M.; Ravelonandro, M.; Scorza, R. Role of the 26nt siRNA in the resistance of transgenic Prunus domestica graft inoculated with Plum pox virus. Virus Genes 2008, 36, 215-220. [CrossRef]

23. Hily, J.M.; Scorza, R.; Webb, R.; Ravelonandro, M. Accumulation of the long class of siRNA is associated with resistance to Plum pox virus in transgenic woody perennial plum tree. Mol. Plant-Microbe Interact. 2005, 8, 794-799. [CrossRef] [PubMed]

24. Ravelonandro, M.; Briard, P.; Monsion, M.; Scorza, R. Stable transfer of the Plum pox virus capsid transgene to seedlings of the French cultivars Prune D'ente 303 and Quetsches 2906 and preliminary results of PPV challenge assays. Acta Hortic. 2002, 577, 91-96. [CrossRef]

25. Hily, J.M.; Scorza, R.; Malinowski, T.; Zawadzka, B.; Ravelonandro, M. Stability of gene silencing-based resistance to Plum pox virus in transgenic plum (Prunus domestica L.) under field conditions. Transgenic Res. 2004, 13, 427-436. [CrossRef]

26. Zhou, H.; Xia, G.X.; Xu, Z. An RNA polymerase II construct synthesizes short-hairpin RNA with a quantitative indicator and mediates highly efficient RNAi. Nucleic Acids Res. 2005, 1, e62. [CrossRef]

27. Hoffer, P.; Ivashutab, S.; Pontesc, O.; Vitinsc, A.; Pikaardd, C.; Mroczkaa, A.; Wagnera, N.; Voelkera, T. Posttranscriptional gene silencing in nuclei. Proc. Natl. Acad. Sci. USA 2011, 108, 409-414. [CrossRef]

28. Hammond, S.M.; Caudy, A.A.; Hannon, G.J. Post transcriptional gene silencing by double stranded RNA. Nat. Rev. Genet. 2001, 2, 110-119. [CrossRef]

29. Ravelonandro, M.; Briard, P. Mechanisms of natural and genetically engineered resistance against viruses. In Applied Plant Virology, Advances, Detection and Antivral Strategy; Academic Press: New York, NY, USA, 2020; Chapter 49. [CrossRef]

30. Gao, Z.; Liu, H.L.; Daxinger, L.; Pontes, O.; He, X.; Qian, W.; Lin, H.; Xie, M.; Lorkovic, Z.J.; Zhang, S.; et al. An RNA polymerase II- and AGO4-associated protein acts in RNA-directed DNA methylation. Nature 2010, 465, 106-109. [CrossRef] [PubMed]

31. Ravelonandro, M. Transgenic virus resistance using homology-dependent RNA silencing and the impact of mixed virus infection. In Biotechnology and Plant Disease Management; Zamir, K., Punja, S., De Boer, S., Sanfacon, H., Eds.; CABI: New York, NY, USA, 2007; Chapter 49; pp. 374-394.

32. Zagrai, I.; Ravelonandro, M.; Zagrai, L.; Scorza, R.; Minoiu, N. Overview of the investigations of transgenic plums in Romania. Acta Horticult. 2011, 899, 153-158. [CrossRef]

33. Polák, J.; Kundu, J.; Krška, B.; Beoni, E.; Komínek, P.; Pívalova, J.; Jarošová, J. Transgenic plum Prunus domestica L. clone C5 (cv. HoneySweet) for protection against sharka disease. J. Integr. Agric. 2017, 16, 516-522. [CrossRef] 